\title{
Gore's satellite may fill role of lost SOHO
}

[WASHINGTON] An Earth-viewing satellite that few Earth scientists want may be of more use to space physicists stunned by the apparent loss of the US-European Solar and Heliospheric Observatory (SOHO) (see Nature 394, 5; 1998).

The US space agency NASA last week asked for proposals for the Triana spacecraft, suggested by US Vice-President Al Gore in March as a way of inspiring the public with live pictures of Earth taken from space (see Nature 392, 220; 1998).

The $\$ 50$ million satellite, to be launched in late 2000 (when Gore is expected to be campaigning for the presidency), would be parked in a stable orbit 1.5 million kilometres from Earth in the direction of the Sun.

According to a reference mission design provided by NASA, the only instrument on board would be a colour camera capable of returning a new image of the whole Earth every three minutes. The best resolution would be 14 kilometres; this is poor by the standards of the remote-sensing satellites now in Earth orbit, which can see details as small as a few metres across.

Earth scientists have been largely indifferent to Gore's idea, or have grumbled, in private, that it may take funds from more legitimate peer-reviewed projects. Most of the scientists who answered an informal NASA request for ideas for Triana in April proposed adding something else to the satellite, such as solar radiation sensors or a more capable camera.

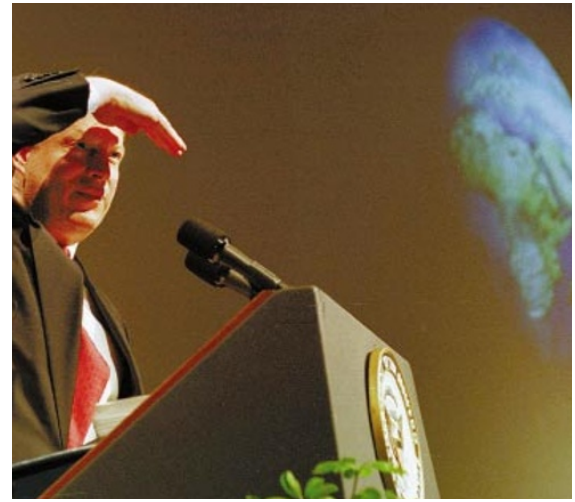

Earth in view: Gore's announcement (above) of his Triana project has met criticism in Congress.

Such extras may in fact be necessary to save the project. Appropriators in the US House of Representatives have blocked funding for Triana until NASA can show based on the proposals it receives by the end of August - that the idea has support in the scientific community or private sector.

"NASA must demonstrate for the [appropriations] committee that the agency has a plan for a public-private, peerreviewed mission, which has resulted from a competitive process," wrote the lawmakers in a report accompanying NASA's 1999 spending bill. The chairman of the House subcommittee on space, Dana Rohrabacher (Republican, California), has dismissed Triana as a " $\$ 50$ million politically correct screensaver".
NASA's solicitation encourages proposers to embellish the basic single-camera concept, as long as they supply the additional funds. The fact that Triana is destined for the same unusual orbit as $\mathrm{SOHO}$ has drawn the attention of NASA managers working on contingency plans should the $\$ 1$ billion solar observatorybe declared a loss.

George Withbroe, who heads NASA's solar and space physics programme, says it may be several months before SOHO's fate is known, as its solar panels may slowly turn to catch enough sunlight to repower its batteries. Although engineers are uncertain this will work, or what condition $\mathrm{SOHO}$ would be in after a long dormant period, Withbroe says "I'm not going to write it off yet."

But, to preserve the option of launching some solar-observing instruments in time to monitor the solar sunspot maximum expected to begin next year, officials from NASA and the European Space Agency have already started looking at quick, cheap recovery plans. Triana's fast track to launch makes it especially appealing.

The proposed spacecraft is much smaller than SOHO, but Withbroe says it may be able to piggy-back some high-priority instruments, such as a coronagraph, if necessary.

NASA is looking at other options, such as speeding up the STEREO solar-imaging mission now planned for launch in 2004.

US and European space managers will meet this month for further discussions on recovery plans for SOHO. Tony Reichhardt

\section{Biologists recommend scrapping NASA's research on crystals}

[WASHINGTON] A panel of biologists reviewing the US space agency NASA's life science research programme has called for an end to protein crystallography experiments in space - one of the highest-profile research activities planned for the International Space Station.

The committee of the American Society for Cell Biology (ASCB) also says that research into "basic animal and plant cell and developmental biology cannot be used to justify a space mission".

The panel of seven scientists was chaired by Donald Brown, a developmental biologist at the Carnegie Institution of Washington, DC. It was asked by ASCB president Elizabeth Blackburn of the University of California at San Francisco to develop a view on life science research in space in the light of opposition voiced by some biologists.

The resulting report was passed unanimously by the society's governing council last month, and includes some of the most pointed criticism ever levelled at NASA research by a scientific body.
The panel called space-based experiments to investigate gravity-sensing organs "premature" until more basic research is done on the ground. The group saw potential value in NASA ground-based plant research, but said that space experiments in general should have to justify their great cost, considering that the space station "will be the most expensive and inflexible laboratory ever built".

The harshest words were reserved for protein crystal growth in space, which NASA-funded researchers claim is useful in drug design. "No serious contributions to knowledge of protein structure or to drug discovery or design have yet been made in space," wrote the panel. "This committee recommends that no further funds be spent on crystallization of proteins in space."

Panel member Ursula Goodenough of Washington University in St Louis, a past president of the ASCB and a space station critic, said the group strayed somewhat from its territory of cell biology in judging the NASA crystallography work. But she says that the presence on the panel of experts such as protein researcher Stephen Harrison of Harvard gave the committee confidence in its conclusion. Other members were Anthony Mahowald of the University of Chicago, Elliot Meyerowitz of the California Institute of Technology, Christopher Somerville of Stanford University and Carnegie, and Andrew Staehelin of the University of Colorado.

Tim Roemer (Democrat, Indiana), the space station's chief opponent in the US House of Representatives, was due to hold a press conference this week to publicize the report as part of his annual attempt to cancel the station when it comes to a House vote. That effort is almost certain to fail, just as a similar attempt failed in the Senate last week by a vote of 66 to 33 .

Although the ASCB report is unlikely to have any real effect on the fate of the station, which begins construction this year, it is embarrassing for NASA, whose administrator, Daniel Goldin, has enlisted biologists' support for space research. T.R. 